\title{
The U.S. Biofuel Policy: Review of Economic and Environmental Implications
}

\author{
Naveen Adusumilli ${ }^{1, *}$, Andrew Leidner ${ }^{2}$ \\ ${ }^{1}$ LSU AgCenter \\ ${ }^{2}$ Former student, Department of Agricultural Economics, Texas A\&M University, College Station, Texas, USA \\ *Corresponding author: nadusumillli@agcenter.lsu.edu
}

Received July 15, 2014; Revised August 08, 2014; Accepted August 12, 2014

\begin{abstract}
A major national initiative to generate renewable fuels from plant matter has taken shape in the U.S., primarily to reduce dependency on foreign oil and achieve reduction in greenhouse gases. However, the biofuel policies in the U.S. ignored for the most part, the potential synergies between food and biofuel production. As a result, their production has produced negative impacts on food security, natural resources, and climate. This paper reviews some of the recent literature identifying the economic and environmental consequences of the U.S. renewable fuel policy. The aim of this review is to understand the key regional threats to water security in the context of projected food and energy demand growth. Failure to account for unintended consequences in future policy development can jeopardize achieving the energy, agricultural, and environmental policy goals of the biofuels program.
\end{abstract}

\section{Keywords: biofuels, food security, climate, natural resources, policy}

Cite This Article: Naveen Adusumilli, and Andrew Leidner, "The U.S. Biofuel Policy: Review of Economic and Environmental Implications.” American Journal of Environmental Protection, vol. 2, no. 4 (2014): 64-70. doi: 10.12691/env-2-4-1.

\section{Introduction}

With the United States' (U.S.) growing concerns over energy consumption and environmental quality, policies in the Clean Air Act evolved to mandate use of alternative fuels, aiming reducing dependency on imported oil, providing expanded market for agricultural products such as corn and soybeans, and reducing greenhouse gas (GHG) emissions from the U.S. transportation sector [1]. Consequently, a major national initiative to generate renewable fuels, emphasizing on ethanol and biodiesel has taken shape. The U.S. has tried to build a viable biofuels industry in two ways: by imposing quantity-based constraints on biofuels productions and by offering biofuel producers a package of financial, primarily tax-related incentives (although some of the incentives have expired). Congress passed several pieces of energy legislation to introduce Renewable Fuels Standards (RFS). The RFS requires producing and blending of several different classes of biofuels, eventually requiring 36 billion gallons per year of biofuels be blended with petroleum fuels in 2022. Since implementation of the biofuels policy, the biofuel industry has required heavy policy support from Congress. The dependence of the biofuels industry on ongoing federal policy as well as the far-reaching market effects and other unintended consequences has altered views about biofuels.

Integration of the agricultural and energy sector through biofuel policies have produced major concerns at the national level, such as economic impacts on the agricultural markets [2,3], soil erosion [4,5], water quantity and quality depletion [6,7], and biodiversity loss [8]. Continual reliance on biofuels can have wide spread ripple effects and can jeopardize achieving the energy, agricultural, and environmental policy goals of the biofuels program. The goal of this paper is to examine recent and ongoing research on the economic and environmental outcomes of the U.S. biofuels policy. The literature reviewed is not exhaustive; nevertheless, it demonstrates that the costs clearly outweigh the benefits associated with the U.S. biofuels policy.

\section{Biofuels Overview}

Biofuels are liquid, solid, or gaseous fuels derived from renewable biological sources. Biofuels include ethanol and various other alcohol-based fuels, pyrolysis oils, gasification fuels, and biodiesel. Renewable biological sources include but are not limited to food crops, energy crops, crop residue, wood waste and byproducts, and animal manure. Although ethanol can be produced from any biological material that contains appreciable amounts of sugar (or materials that can be easily converted to sugar such as starch), U.S. ethanol production has almost exclusively relied on cornstarch. Approximately 13.3 billion gallons of ethanol were produced in the U.S. in 2013 [9] with over 95 percent coming from corn-starch.

Because of concerns over significant use of corn toward ethanol production, interest has grown in fuels produced 
from cellulosic biomass materials such as crop residue, biomass from switchgrass and high-energy sorghum. However, many uncertainties remain concerning both the viability and the speed of commercial development of cellulosic biofuels. Another important component of U.S. biofuel industry is biodiesel. Biodiesel can be produced from a variety of feedstocks, including agricultural oils such as soybean oil, canola oil, and animal fats. According to U.S. Energy Information Administration (EIA), soybean oil remains the largest single source of biodiesel feedstock in the U.S. with a share of over 53 percent in 2013 [10].

\section{Biofuels Policy in the U.S.}

Biofuels policy in the U.S. is characterized by efforts, ongoing since about 2006, to promote and support a domestic biofuels industry. The types of policy interventions range from mandates that target specific production quantities for biofuels and biofuel-related products, to restrictions associated with greenhouse gas (GHG) emissions, to financial incentives such as direct payments and tax incentives. The majority of biofuel policy has been made at the federal level, frequently in conjunction with the farm bill or with environmental laws, such as the Clean Air Act. Many U.S. states have also augmented the federal effort with their own state-specific biofuels policies.

\subsection{Biofuels Production Mandates in Federal Policy}

Several legislative and regulatory developments have affected biofuels over the past few years. The Energy policy Act of 2005 amended the Clean Air Act and established the first renewable fuel program, referred to as Renewable Fuel Standard (RFS) program. Under the program, U.S. Environmental Protection Agency (EPA) ensures that gasoline sold in the U.S. contains specific volumes of renewable fuels for each calendar year. This initial RFS (referred to as RFS1) mandated specific volumes of renewable fuel be produced and blended starting in year 2006 through 2012. The volume requirements are shown in Table 1.

In the years since RFS1 initially passed in 2006, several changes have been made to the original program. Specifically in 2007, the Energy Independence and Security Act (EISA) modified RFS1 and enacted the second and most recent RFS program, called RFS2. Some of the key changes introduced in RFS2 include the following: RFS2 mandated a minimum of 9.0 billion gallons of renewable fuel be produced and blended in the nations' gasoline supply starting 2008 [11], and required this minimum volume increase to 36 billion gallons per year by 2022 (Table 1). Also in RFS2, the list of retail fuel products that can be blended with renewable fuels was expanded to include most other transportation fuels, most notably including diesel intended for use in highway motor vehicles, non-road use vehicles (e.g., use in agricultural equipment), and marine vehicles. Furthermore, through 2022, additional volume restrictions and targets were set for specific sub-categories of renewable fuels.

Table 1. Renewable Fuel Volume Requirements in Billion Gallons as approved by the U.S. Environmental Protection Agency RFS2 Biofuel Mandate

\begin{tabular}{|c|c|c|c|c|c|c|}
\hline \multirow[t]{2}{*}{ Year } & \multirow[t]{2}{*}{ RFS1 Biofuel Mandate } & \multirow[b]{2}{*}{ Total Renewable Fuel } & \multirow[b]{2}{*}{ Cap on Corn Ethanol } & \multicolumn{3}{|c|}{ Portion from Advanced (non-corn) Biofuels } \\
\hline & & & & Total Advanced Biofuel & Cellulosic Biofuel $^{\mathrm{a}}$ & Biodiesel $^{\mathrm{a}}$ \\
\hline 2006 & 4.00 & 4.00 & 4.00 & & & \\
\hline 2007 & 4.70 & 4.70 & 4.70 & & & \\
\hline 2008 & 5.40 & 9.00 & 9.00 & & & \\
\hline 2009 & 6.10 & 11.10 & 10.50 & 0.60 & & $0.50(0.00)$ \\
\hline 2010 & 6.80 & 12.95 & 12.00 & 0.95 & $0.10(0.0065)$ & $0.65(1.15)$ \\
\hline 2011 & 7.40 & 13.95 & 12.60 & 1.35 & $0.25(0.0060)$ & 0.80 \\
\hline 2012 & 7.50 & 15.20 & 13.20 & 2.00 & $0.50(0.0140)$ & 1.00 \\
\hline 2013 & & 16.55 & 13.80 & 2.75 & $1.00(0.0060)$ & $1.00(1.28)$ \\
\hline 2014 & & 18.15 & 14.40 & 3.75 & 1.75 & $\mathrm{~b}$ \\
\hline 2015 & & 20.50 & 15.00 & 5.50 & 3.00 & $\mathrm{~b}$ \\
\hline 2016 & & 22.25 & 15.00 & 7.25 & 4.25 & $\mathrm{~b}$ \\
\hline 2017 & & 24.00 & 15.00 & 9.00 & 5.50 & $\mathrm{~b}$ \\
\hline 2018 & & 26.00 & 15.00 & 11.00 & 7.00 & $\mathrm{~b}$ \\
\hline 2019 & & 28.00 & 15.00 & 13.00 & 8.50 & $\mathrm{~b}$ \\
\hline 2020 & & 30.00 & 15.00 & 15.00 & 10.50 & $\mathrm{~b}$ \\
\hline 2021 & & 33.00 & 15.00 & 18.00 & 13.50 & $\mathrm{~b}$ \\
\hline 2022 & & 36.00 & 15.00 & 21.00 & 16.00 & $\mathrm{~b}$ \\
\hline
\end{tabular}

${ }^{\mathrm{a}}$ The number in the parenthesis indicates revised mandate.

${ }^{\mathrm{b}}$ To be determined by EPA through a future rulemaking, but no less than 1.0 billion gallons.

Source: RFS1biofuel mandate [1]; RFS2 biofuel mandate [11]; revised mandates [46,47,48]. 
A maximum of 15 billion gallons of ethanol produced from cornstarch, with the remaining 21 billion gallons production subdivided into three nested categories cellulosic biofuels, biodiesel, and advanced biofuels. Advanced biofuels are defined as biofuels derived from materials other than cornstarch along with having 50\% lower lifecycle GHG emissions compared to emissions in year 2005 from gasoline [11] (U.S. EPA, 2010a). As shown in the Table 1 , the volume requirements are not exclusive. Any renewable fuel that meets the requirement for cellulosic biofuel or biodiesel is also valid for meeting the advanced biofuel requirement. Likewise, any renewable fuel that meets the requirement for advanced biofuel is also valid for meeting the total renewable fuel requirement [11].

Under the RFS program, EPA is required to annually determine the projected volume production of cellulosic biofuels and biodiesel based on EIA's projections on progress of construction of large scale advanced biofuel production facilities, current and expected funding toward advanced biofuel research, status of technology utilized, and a variety of other factors. As a result, EPA established new volume requirements for cellulosic biofuel and biodiesel, shown in parentheses in the cellulosic biofuel and biodiesel columns in Table 1.

\subsection{Greenhouse Gas Requirements for Biofuels}

In addition to renewable fuel volume requirements, GHG emissions thresholds were introduced for various categories of renewable fuels. GHG emission thresholds were intended to curb pollution and improve public health [11]. To qualify as a renewable fuel, lifecycle emissions (i.e., emissions involved in production and transport of feedstock, processing, distribution, and end use of the renewable fuel) are required to be lower than the lifecycle emissions in 2005 by petroleum fuels. Table 2 presents GHG thresholds specified in the EISA.
Table 2. Percent Lifecycle GHG Reduction Thresholds Specified in Energy Independence and Security Act (EISA) for Each Renewable Fuel Category $^{\text {a }}$

\begin{tabular}{|c|c|}
\hline Biofuel Category & Percent Reduction \\
\hline Renewable fuel $^{\mathrm{b}}$ & $20 \%^{c}$ \\
\hline Biodiesel & $50 \%$ \\
\hline Cellulosic biofuel & $60 \%$ \\
\hline Advanced biofuel & $50 \%$ \\
\hline $\begin{array}{l}{ }^{\text {a Percent Reduction }} \\
\text { Emissions in Year } \\
{ }^{b} \text { Renewable fuel in } \\
\text { and advanced biofu } \\
{ }^{c} \text { Applies to renewa } \\
\text { after Dec 19, 2007. } \\
\text { Source: [11]. }\end{array}$ & $\begin{array}{l}\text { Petroleum Fuels } \\
\text { sel, cellulosic ethanol, } \\
\text { commenced construction }\end{array}$ \\
\hline
\end{tabular}

U.S. Federal policy incentivizes biofuel production using three primary tools: (1) offering tax credits to biofuel blenders; (2) imposing import duty on fuel ethanol; and (3) offering direct payments to producers of non-corn biofuel feedstocks and to biofuel manufacturing facilities toward purchasing biomass [12]. Biofuel tax credits were claimed primarily on producing and blending of biofuels with petroleum fuels and varied according to the type of biofuel and feedstock used to produce that fuel [13]. Federal tax credits for biofuels are presented in Table 3.

As [14] discusses, incentives are required in the early stages of new industry development but can be discontinued once the industry becomes established unless marginal social benefits are substantially higher than marginal costs. Putting Miranowski's argument in the context of the biofuels industry, ongoing incentives to continue expansion of US ethanol industry may have been perceived to be unnecessary, especially in periods of high gasoline prices. As a result, tax credits were allowed to expire.

Table 3. Federal Tax Credits for Ethanol and Biodiesel

\begin{tabular}{|c|c|c|c|c|c|}
\hline Biofuel & Name of the Incentive & Description & $\begin{array}{l}\text { Credit } \\
\text { (US\$) }\end{array}$ & Gallon & Expiration \\
\hline Ethanol & 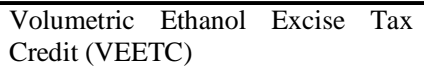 & $\begin{array}{l}\text { blenders credit for ethanol (regardless of the } \\
\text { feedstock) blended with gasoline for sale or use }\end{array}$ & & 0.45 & Dec 31, 2011 \\
\hline $\begin{array}{l}\text { Cellulosic } \\
\text { ethanol }\end{array}$ & $\begin{array}{l}\text { Cellulosic Biofuel Producer Tax } \\
\text { Credit (CBPTC) }\end{array}$ & $\begin{array}{l}\text { blenders credit for cellulosic ethanol blended with } \\
\text { gasoline for sale or use }\end{array}$ & & $1.01^{\mathrm{a}}$ & Dec 31, 2012 \\
\hline Biodiesel & Biodiesel Excise Tax Credit & $\begin{array}{l}\text { blenders credit for mixing petroleum diesel with } \\
\text { biodiesel }\end{array}$ & & 1.00 & Dec 31, 2013 \\
\hline $\begin{array}{l}\text { Ethanol and } \\
\text { Biodiesel }\end{array}$ & $\begin{array}{l}\text { Small Ethanol Producer Tax Credit } \\
\text { (SEPTC) }^{\mathrm{b}} \text {; } \\
\text { Small Agri-Biodiesel Producer }{ }^{\mathrm{b}} \text { Tax } \\
\text { Credit }\end{array}$ & $\begin{array}{l}\text { blenders credit to produce ethanol fuel mixture for } \\
\text { sale or use; blenders credit to produce biodiesel } \\
\text { fuel mixture for sale or use }\end{array}$ & & 0.10 & Dec 31, 2011 \\
\hline
\end{tabular}

${ }^{a}$ Tax credit must be reduced by credit in effect for the mixture of ethanol with gasoline and for small producers.

${ }^{\mathrm{b}}$ A small producer is defined as one that has no more than 60 million gallons per year of productive capacity of any type of biofuel. The credit applies only to the first 15 million gallons.

Source: [49].

In addition to tax credits, U.S. biofuels policy imposed ethanol import tariff of 54 cents per gallon plus 2.5 percent sales tax; these tariffs were levied against ethanol produced from many common types of feedstock-based biofuels including sugar-based ethanol, imported from most countries. Because most imported ethanol was made from sugarcane, imported ethanol was used to fulfill the advanced biofuel requirement.

Several studies reported that elimination of import tariff could contribute toward improving the environment as ethanol produced from sugarcane contributes to reducing GHG emissions far more than ethanol from corn $[15,16]$ and very minimally impact U.S. ethanol and corn market primarily due to a largely saturated U.S. ethanol market [17]. As a result, the import tariff was not renewed once expired at the end of 2011.

One of the other major biofuel incentives introduced in the 2008 Farm Bill is the Biomass Crop Assistance Program (BCAP), funded through 2018. The goal of BCAP is to provide incentives toward production of 
advanced biofuels, which had not kept pace with targets specified in RFS2. According to the [18] fact sheet, BCAP employs three incentives for biomass. One, provide up to 75 percent of the cost for a new establishment of a perennial biomass crop; two, provide annual payments for up to five years to maintain matured herbaceous biomass crop(s) and for up to 15 years to maintain a woody crop; ${ }^{1}$ three, provide matching payments up to $\$ 45$ per dry ton for biomass conversion facilities for the biomass materials. For fiscal year 2009-2010, BCAP provided incentives in the amount of $\$ 244$ million [18].

\subsection{State Biofuels Policy}

In addition to the federal policies, several states have their own tax credits and tax exemptions to support alternative fuel use, reduce U.S. dependency on foreign oil, and promote biofuel industry within their own state. State level biofuel policies are primarily of three types. One, financial incentives, i.e., tax credits, tax exemptions, grants, loans, and funds; two, vehicle acquisition and fuel use requirements, i.e., mandates for government fleet to acquire alternative fuel vehicles that run on biofuels or use certain percentage of biofuels; three, fuel blend standards. States have one or more of these policies. Presented in Table 4 are states' laws and incentives related to alternative fuels.

Table 4. Laws and Incentives Related to U.S. Alternative Fuels

\begin{tabular}{ccccl}
\hline \multicolumn{5}{c}{ Biofuel Incentive/Policy } \\
\hline $\begin{array}{c}\text { Financial } \\
\text { Incentives }\end{array}$ & $\begin{array}{c}\text { Vehicle } \\
\text { Acquisition }\end{array}$ & $\begin{array}{c}\text { Fuel Use } \\
\text { Requirements }\end{array}$ & $\begin{array}{c}\text { Fuel Blend } \\
\text { Standards }\end{array}$ & \multicolumn{1}{c}{ States } \\
\hline$\checkmark$ & & & & AK, AL, AZ, CT, ID, ME, MI, MS, ND, NY, OH, OK, RI,TN, TX \\
& $\checkmark$ & $\checkmark$ & & CA, IA, NH \\
$\checkmark$ & $\checkmark$ & $\checkmark$ & & AR, CO, GA, IL, IN, KS, KY, MD, NC, NE, SC, SD, SD, VA, VT, WI, DC \\
$\checkmark$ & & & $\checkmark$ & LA, MA, PA, NM, OR \\
$\checkmark$ & $\checkmark$ & $\checkmark$ & $\checkmark$ & FL, HI, MN, MO, MT, WA \\
\hline
\end{tabular}

\section{Economic Effects of Biofuels Policy}

In many ways, biofuels policy directly impacts the business decisions and profitability of the biofuel feedstock producers and the biofuels manufacturers who process, distribute, and retail the final biofuel product to consumers. However, some effects of biofuels policy throughout the biofuels supply chain are less direct. These less direct effects include changes to cropping acreages and commodity prices, which can be measured in agricultural producer profitability and benefits or harms to consumers.

\subsection{Crop Acres}

With biofuel mandates and associated subsidies potentially influencing decisions to produce biomass crops and affecting the profit margins for ethanol processing plants, cropping pattern changes occurred across the U.S. In the U.S., approximately 96 million acres were planted to corn crop in year 2013, up over 15 million acres from 2000 [19]. Much of the additional acres came out of soybean acreage. It is estimated that increased harvested corn acreage in Iowa, Michigan, Minnesota, and Wisconsin in year 2007 primarily came at the expense of harvested soybean acreage [20]. Similarly, in Iowa, one of the primary states in the U.S. Corn Belt, percentage of soybean acres to corn acres has been dropping since 2001 [21]. It is also reported in [21] that in 2011, Iowa harvested approximately 9.0 million soybean acres compared to 13 million corn acres, which means one-third of the corn is continuous corn given the states historic cropping patterns. Such major cropping pattern changes due to biofuel production will cause increase in prices of crops substituted for biofuel crop production. Although producers gain, consumers lose from higher prices.

\subsection{Crop Prices and Food Costs}

Land-use conversion for cultivation of biofuel crops and diversion of corn toward ethanol production will translate into higher food prices across the globe. This is especially true for the crops used to produce biofuels. The effect of biofuels increased market prices by 9.0 percent for coarse grains (e.g., corn, sorghum, wheat) in the U.S., 10 percent for oil seeds in the European Union (EU), and 11 percent for sugarcane in Brazil [22]. According to the [23], world food prices increased by 45 percent since 2006, mainly due to increased consumption and new biofuel mandates in the U.S. and EU. In a more recent analysis, [24] estimated that corn ethanol production during 2006/2007 produced approximately 27 percent rise in corn price during the same period. The increase in biofuel production during the mid-2000s constitutes a shock to the demand for corn as a fuel source that resulted in higher prices of corn for food.

Although corn and soybean account for more than 90 percent of the feedstock used to produce biofuels in the U.S., the effect of the RFS mandate has effects extending into production decisions and prices of all crops. It is anticipated that because of RFS production, corn and wheat prices would increase by 50 percent and soybean prices by 28 percent by year 2022, compared to their prices at zero biofuel production [25]. Higher commodity prices of basic staples used in the manufacture of retail food products would, consequently, increase the cost of many products in the retail food sector as much as \$22 billion in increased food costs for the U.S. consumers, in 2007 prices [26]. And approximately, \$15 billion of this increase was attributed to the surge in demand for feed crops for fuel. With approximately 100 million metric tons in corn, soybeans, and wheat exports from the U.S. during 2011-12 [27], massive increase in the use of food crops for fuel will increase retail food costs for consumers across the globe. Therefore, continued biofuel production could have serious food security challenges.

\subsection{Welfare Effects}


Increase in food prices accompanied by taxed-based biofuel incentives constituted substantial costs to food consumers and U.S. taxpayers. Alternatively, agricultural producers benefit from increase in net farm income due mainly to the high prices for biofuel feed crops as well as other major crops. The aggregate economic surplus estimates still suggest a net loss [28,29]. [25] estimated a loss of \$56 billion per year to consumers from higher crop prices because of production of the RFS mandate by 2022, assuming land coming out of CRP remains in some conservation practice. However, allowing marginal lands currently in conservation use to return to production resulted in partial reduction in crop prices. With more land, conventional wisdom suggests that farmers would be better off financially. However, due to price elasticity of demand, the lower commodity prices more than offset the increase in acres, resulting in a lower net income and consequently lower total economic surplus. Hence, the tight linkage between energy and agricultural sector indicate that negative economic impacts are ominous.

The economic surplus impacts identified above do not include possibly positive effects to consumers via expanded fuel production. However, accounting for the fossil fuels for production and conversion of ethanol, the net addition to the fuel supply from production of 36 billion gallons of biofuels is approximately 7.5 billion gallons [30], which is only six percent of total U.S. gasoline use in 2011 [31].

\section{Environmental Effects of Biofuel Policy}

Present policies encouraging biofuels production are having some negative impacts by accelerating depletion of water resources as well as increase GHG emissions [32]. Some of the environmental consequences reflect impacts on water quality, water quantity, biodiversity, and air quality. Several studies have provided estimates of these impacts.

\subsection{Biofuels and Water Quality}

Biofuels impact on water quality will depend on management practices such as application of fertilizers and tillage practices, which affect nutrient and sediment loads to water bodies. Increase in corn acreage to meet RFS primarily occurred in corn-soybean rotation regions of the U.S., resulting in corn-on-corn acreage [20,21]. Such monocropping mean higher nutrient applications, resulting in greater discharges of pollutants to surface and ground waters. [33] estimated that a 5 million acre shift from soybean to corn acreage results in increases of 3.8, 1.7, and 1.3 percent in $\mathrm{N}, \mathrm{P}$, and $\mathrm{K}$ fertilizer use, respectively. It is also predicted that $10-34$ percent increase in dissolved nitrogen export to the Gulf of Mexico due to ethanol production required to meet the U.S. RFS [34]. Similarly, [5] estimated that expansion of biofuels production to Conservation Reserve Program (CRP) lands would result in 145 million tons in increased erosion annually at an expense of $\$ 11.13$ per ton of soil erosion to meet the biofuel mandate. Therefore, without a complementary increase in soil and water conservation efforts, increased fertilizer use due to expanded and intensive crop production has the potential to lead to increased nutrient and sediment losses to surface and groundwater.

Although management practices could reduce some of the potential negative water quality impacts that could occur through sediment and nutrient runoff from croplands, these practices involve substantial costs and can quickly erode the profits of the producers. The aggregate costs of mitigation for sediments, nitrates, and phosphates runoff because of shifting grassland to biomass crop production are in the range of $\$ 5,800$ to $\$ 116,000$ per ton per year [7]. With the biofuel agricultural landscape dominated by input intensive crops such as corn as well as conversion of conservation land to crop production, nutrient and sediment runoff to water bodies is exacerbated. While management practices lead the way to ameliorate nutrient and sediment pollution, because their adoption can substantially affect farm profitability the prospect for a large movement towards such management practices seems unlikely.

As noted earlier, increase in net farm income from biofuels crop production will provide agricultural producers with incentives for intensive application of fertilizers, cultivate marginal lands, and otherwise alter current cultural practices. Such production practices make land resources vulnerable to erosion and loss of productivity that ultimately causes increased pollution discharges to waterways and would involve substantial mitigation costs to internalize the externality unless farmers also modify methods of fertilizer application to achieve greater efficiency and smaller losses.

\subsection{Biofuels and Water Use}

Biofuel crop production and/or biofuel refining increases demand for water. The water requirements of biofuel production depend on type of feedstock, geographic and climatic characteristics. In major corn producing regions in the U.S., the upper and lower Midwest, corn cultivation uses 7.0 to 321 gallons of irrigation water for every gallon of ethanol produced [35]. Studies have shown that water use at ethanol production facilities using corn are slightly over 4 gallons per gallon of ethanol in 2005 [36], which means that a 100 million gallon per year ethanol facility will withdraw 400 million gallons per year from surface and/or groundwater sources. Biofuels expansion, especially in water-stressed agricultural areas, increases water consumption and put pressure on already scarce water resources.

Impacts on water resources will be felt at regional and local levels where water resources are already stressed. Currently operational 33ethanol plants overlying the Ogallala aquifer region reported an annual water use of 2.6 billion gallons per year [37]. Such increased demand for already scarce water resources creates added pressure on nations' water resources, affecting the sustainability of the resource as well as the region, and posing a major roadblock to achieve the underlying policy goals of the biofuels program.

\subsection{Biofuels and Biodiversity}

The impact of biofuels on biodiversity depends on which habitats are converted. Land demand for biofuel crops could result in conversion of CRP land, usually a grassland habitat to crop production. The CRP has 
benefited wildlife [38,39], beyond reducing soil erosion and improving water quality [40]. The expansion of crop production to these lands may threaten the gains made in conservation of biodiversity.

In the U.S., an aggregate of 17 million acres exited CRP from 2006 to 2013 [41], potentially returning to crop production. [42] found that CRP land was abundant in vertebrate diversity and their abundance is threatened by conversion of such land to row crops, consistent with other work demonstrating the wildlife benefits (e.g., sustaining populations of fish, nesting birds, and mammals) of CRP [43]. Hence, expanded biofuel production that induced CRP land to return to production, reversing any conservation and environmental benefits that may have been achieved with the program.

\subsection{Biofuels and Greenhouse Gas Emissions}

Biofuels can increase or decrease GHG emissions and other air pollutants relative to fossil fuels. Emissions can come from land-use change, biofuel production process, and tailpipe emissions from farm and transportation vehicles. Land-use conversion from conservation to biofuel crop production leads to increased GHG emissions and a negative carbon balance [44]. Similarly, an estimated increase in emissions by 50 percent over 30 years from land use changes to support biofuel production [32]. While biofuels production was previously thought to reduce GHG emissions, several studies have since argued that biofuels does not provide GHG benefit into the future if effects of land use change are taken into account [45]. Biofuels can contribute to GHG mitigation only if significant emissions from land use change are avoided. However, with biofuel production potentially causing conservation land to return to agricultural production, net reductions in GHG emissions seems unlikely, seriously challenging the environmental policy goal of the biofuels program.

\section{Summary and Conclusion}

Present policies encouraging biofuels production are having negative impacts on consumers and the environment by accelerating depletion of land and water resources and affecting food security and affordability through increased commodity prices. Along with achieving energy independence and reduction in GHG emissions, policies should also target sustainability goals including land and water conservation, biodiversity, and impact of demand of food crops for fuel on commodity prices in the U.S. and international markets.

In many regions of the U.S., water resources have already been stressed. Water quality continues to be an issue in several key watersheds across the U.S. Environmental benefits achieved through conservation programs are jeopardized by returning these lands to agricultural crop production. New biofuel policies that carefully examine the long-run resource impact of biofuels should be formulated, an absence of which could become a major roadblock to achieving the underlying goals of the nation's energy policy.

An irony of U.S. biofuel's policy is that the biofuel policy has been strongly associated with environmental legislature (Clean Air Act) and energy policy that purportedly intends to address concerns over GHG emissions. When in fact, the biofuels policy by incentivizing expanded production of biofuel feed crops may actually work to the contrary of these environmentaland energy-related policy objectives. Approaching a decade after the first biofuels policy and the influence of biofuels production on net GHG emissions remains unknown. Incentives that have driven the dramatic expansion of U.S. ethanol industry could now be used toward ameliorating the impact of biofuel crop production on water use and quality. It is important to design policies that consider potential increase in nutrient and sediment loading to waters and ways to reduce those loadings. Incentives to producers adopting water management practices, nutrient management, and/or engaged in voluntary conservation, in areas that would yield greatest environmental benefits could be developed.

\section{Endnotes}

1. Exempt from these payments are conventional food and feed crops and invasive species.

\section{Acknowledgements}

Work on this paper was completed while the coauthors were housed in the Department of Agricultural Economics at Texas A\&M University. Views, opinions, and results presented in the paper do not necessarily represent those held by their current or past employers.

\section{References}

[1] U.S. Environmental Protection Agency. EPA finalizes regulations for a renewable fuel standard (RFS) program for 2007 and beyond, Office of Transportation and Air Quality, EPA420-F-07019, 2007.

[2] Rosegrant, M.W. Biofuels and grain prices: Impacts and policy responses, Testimony to the U.S. Senate Committee on Homeland Security and Governmental Affairs, International Food Policy Research Institute, 2008.

[3] Huang, W.-Y. Factors contributing to the recent increase in U.S. fertilizer prices, 2002-08. U.S. Department of Agriculture, Economic Research Service, AR-33, 2009.

[4] Lal, R. "Soil quality impacts of residue removal for bioethanol production,” Soil and Tillage Research, 102(2), 233-241, 2009.

[5] Taylor, C.R., \& Lacewell, R.D. "Effects of corn ethanol and soybased biodiesel production on soil erosion and return of conservation reserve program land to crop production,"BioEnergy Policy Brief, BPB 070409, 2009a. Available: http://www.ag.auburn.edu/biopolicy/. [Accessed March 1, 2014].

[6] National Research Council. "Water implications of biofuels production in the United States,"2007. Available: http://dels.nas.edu/resources/static-assets/materials-based-onreports/reports-in-brief/biofuels_brief_final.pdf. [Accessed Feb 15, 2014].

[7] Adusumilli, N.C., Rister, M.E., Lacewell, R.D., Lee, T., \& Blumenthal, J. "Mitigating externalities related to land use change for biomass production for energy in the Tres-Palacios river watershed of Texas,” 2013a.Available: http://www.ag.auburn.edu/biopolicy/. [Accessed March 1, 2014].

[8] Melillo, J., Reilly, J., Kickligher, D., Gurgel, A., Cronin, T., Paltsev, S., Felzer, B., Wang, X., Sokolov, A., \& Schlosser, C.A. "Indirect emissions from biofuels: How important?"Science, 326(5958), 1397-1399, 2009.

[9] Renewable Fuels Association. "Historic U.S. fuel ethanol production,"2014. Available: 
http://www.ethanolrfa.org/pages/statistics. [Accessed March 2, 2014].

[10] U.S. Energy Information Agency. "Monthly biodiesel production report,”2014. Available:

http://www.eia.gov/biofuels/biodiesel/production/. [Accessed March 5, 2014].

[11] U.S. Environmental Protection Agency. EPA finalizes regulations for the national renewable fuel standard program for 2010 and beyond, Office of Transportation and Air Quality, EPA Report 420-F-10-007, 2010a.

[12] Schnepf, R. Agriculture-based biofuels: Overview and emerging issues, Congressional Research Service Report for Congress, R41282, 2011.

[13] Congressional Budget Office. "Using biofuel tax credits to achieve energy and environmental policy goals,”2010. Available: http://www.cbo.gov/sites/default/files/cbofiles/ftpdocs/114xx/doc1 1477/07-14-biofuels.pdf. [Accessed March 10, 2014].

[14] Miranowski, J.A. "Biofuel incentives and the energy title of the 2007 Farm Bill,” American Enterprise Institute, 2007. Available: http://www.aei.org/docLib/20070515_miranowskifinal.pdf. [Accessed March 1, 2014].

[15] Jank, M.J., Kutas, G., Fernando do Amaral, L., \&Nassar, A.M. EU and U.S. policies on biofuels: Potential impact on developing countries, The German Marshall Fund study, 2007.

[16] Johnson, R.S., \&Runge, C.F. "The brave new world of biofuels: Issues in science and technology," Quarterly Journal of the National Academies of Sciences, 1-6, 2007.

[17] Babcock, B.A., Barr, K., \& Carriquiry, M. Costs and benefits to taxpayers, consumers, and producers from U.S. ethanol policies,Center for Agricultural and Rural Development, Iowa State University. Staff Report 10-SR 106, 2010.

[18] Farm Service Agency. “Biomass Crop Assistance Program,”2011. Available:

https://www.fsa.usda.gov/Internet/FSA_File/bcap_update_may201 1.pdf. [Accessed Feb 20, 2014].

[19] National Agricultural Statistics Service. "National statistics for corn,” 2013.Available:

http://www.nass.usda.gov/Data_and_Statistics/index.asp. [Accessed March 10, 2014].

[20] Landis, D.A., Gardiner, M.M., van der Werf, W., \& Swinton, S.M. "Increasing corn for biofuel production reduces bio-control services in agricultural landscapes," Proceedings of National Academy of Sciences, 105(51), 20552-20557, 2008.

[21] Duffy, M.D. Continuous corn versus corn/soybeans: do the relative prices change the profit comparison?Iowa state University, Ag Decision Maker Newsletter, 2011.

[22] Birur, D.K., Hertel, T.W., \& Tyner, W.E. Impact of biofuel production on world agricultural markets: a computable general equilibrium analysis, Department of Agricultural Economics, Purdue University, GTAP Working Paper No. 53, 2008.

[23] International Monetary Fund (IMF). "Impact of high food and fuel prices on developing countries. Frequently Asked Questions,” IMF External Relations Department. 2008. Available: http://www.imf.org/external/np/exr/faq/ffpfaqs.htm. [Accessed Feb 7, 2014].

[24] Hausman, C., Auffhammer, M., \&Berck, P. "Farm acreage shocks and crop prices: ansvar approach to understanding the impacts of biofuels,"Environmental and Resource Economics, 53(1), 117-136, 2012.

[25] Adusumilli, N.C., Taylor, C.R., Lacewell, R.D., \& Rister, M.E. "Aggregate economic implications of national cellulosic biofuel goals,”2013b. Available: http://www.ag.auburn.edu/biopolicy/. [Accessed March 5, 2014].

[26] Alexander, C., \& Hurt, C. Biofuels and their impact on food prices,Department of Agricultural Economics. Purdue University, ID-346-W, 2007.

[27] U.S. Department of Agriculture. World agricultural supply and demand estimates, WASDE-528, 2014.

[28] Pimentel, D., Patzek, T., \& Cecil, G. "Ethanol production: Energy, economic, and environmental losses,"Reviews of Environmental Contamination and Toxicology, 189, 25-41, 2007.

[29] Taylor, C.R.,\& Lacewell, R.D. "Aggregate economic effects of corn ethanol and soy-based biodiesel production,” BioEnergy Policy Brief, BPB 070209, 2009b.Available: http://www.ag.auburn.edu/biopolicy/. [Accessed March 10, 2014].

[30] Taylor, C.R., Lacewell, R.D., \& Seawright, E. "Economic cost of biodiesel and corn ethanol per net BTU of energy produced,"2010. Available: http://www.ag.auburn.edu/biopolicy/. [Accessed March 10, 2014].

[31] U.S. Energy Information Administration. "Gasoline consumption in the U.S.,”2012. Available: http://www.eia.gov/tools/faqs/. [Accessed Feb 15, 2014].

[32] Searchinger, T., Heimlich, R., Houghton, R.A., Dong, F., Elobeid, A., Fabiosa, J., Tokgoz, S., Hayes, D., \& Yu, T.H. "Use of U.S. croplands for biofuels increases greenhouse gases through emissions from land-use change.”Science, 319(5867), 1238-1240, 2008.

[33] Fixen, P.E. "Potential biofuels influence on nutrient use and removal in the U.S.," Better Crops, 91(2), 12-14, 2007.

[34] Donner, S.D, \&Kucharik, C.J. "Corn-based ethanol production compromises goal of reducing nitrogen export by the Mississippi River," Proceedings of National Academy of Sciences, 105, 45134518, 2008.

[35] Wu, M., Mintz, M., Wang, M., \& Arora, S. Consumptive water use in the production of ethanol and petroleum gasoline, Cente for Transportation Research, Argonne National Laboratory Report ANL/ESD/09-1, 2008.

[36] Phillips, S., Aden, A., Jechura, J., Dayton, D., Eggeman, T. Thermochemical ethanol via indirect gasification and mixed alcohol synthesis of lignocellulosic biomass, Technical report of National Renewable Energy Laboratory, NREL/TP-510-41168, 2007.

[37] Roberts, M.G., Male, T.D., \& Toombs, T.P. "Potential impacts of biofuels expansion on natural resources: A case study of the Ogallala aquifer region,”2007. Available: http://heartland.org/sites/all/modules/custom/heartland_migration/ files/pdfs/22233.pdf. [Accessed March 1, 2014].

[38] Reynolds, R. E. The conservation reserve program and duck production in the U.S. Prairie Pothole Region, J. B. Haufler (Ed.) In Fish and wildlife benefits of Farm Bill conservation programs: 2000-2005 update. Bethesda, Maryland, USA, 2005.

[39] Riffell, S., Scognamillo, D., \& Burger, L.W. "Effects of the conservation reserve program on northern bobwhite and grassland birds,” Environmental Monitoring and Assessment, 146: 309-323, 2008.

[40] FAPRI - Food and Agricultural Policy Research Institute. Estimating water quality, air quality, and soil carbon benefits of the conservation reserve program, FAPRI-UMC report 01-07, 2007.

[41] Farm Service Agency."Conservation programs: Conservative Reserve Program,”2014. Available: http://www.fsa.usda.gov/FSA/webapp?area=home\&subject=copr \&topic $=$ crp. [Accessed Feb 20, 2014].

[42] Fletcher, R.J. Jr, Robertson, B.A., Evans, J., Doran, P.J., Alavalapati, J.R.R., \&Schemske, D.W. "Biodiversity conservation in the era of biofuels: risks and opportunities," Front. Ecol. Environ.

[43] Fargione, J.E, Cooper, T.R., Flaspohler, D.J., Hill, J., \& Lehman, C. "Bioenergy and wildlife: threats and opportunities for grassland conservation,” BioScience, 59,767-777, 2009.

[44] Fargione J., Hill, J., Tilman, D., Polasky, S., \& Hawthorne, P. "Land clearing and the biofuel carbon debt," Science, 319, 12351238, 2008.

[45] Plevins, R. J., O’Hare, M., Jones, A.D., Torn, M.S., \& Gibbs, H.K. “Greenhouse gas emissions from biofuels' indirect land use change are uncertain but may be much greater than previously estimated," Environmental Science and Technology2, 44, 80158021, 2010.

[46] U.S. Environmental Protection Agency. EPA finalizes 2013 renewable fuel standards, Office of Transportation and Air Quality, EPA-420-F-13-042, 2013.

[47] U.S. Environmental Protection Agency. EPA finalizes 2012 renewable fuel standards, Office of Transportation and Air Quality, EPA-420-F-11-044, 2011.

[48] U.S. Environmental Protection Agency. EPA finalizes 2011 renewable fuel standards,Office of Transportation and Air Quality, EPA-420-F-10-056, 2010b.

[49] U.S. Department of Energy. "Federal laws and incentives,”2010 Available:

http://www.afdc.energy.gov/laws/fed_summary. [Accessed March 20, 2014]. 